\title{
Pesquisa e propriedade intelectual envolvendo material humano: afinal, de quem são nossos genes?
}

\author{
Research and intellectual property involving human material: after all, \\ from whom are our genes?
}

\section{La investigación y la propiedad intelectual implicando material humano: ¿al final, a quien pertenecen nuestros genes?}

\author{
Mariana de Melo Santos | marimelos@gmail.com \\ Faculdade de Saúde e Ecologia Humana, Graduação em Medicina. Vespasiano, Minas Gerais, Brasil. \\ Laura Melo Bonfim | lauramelob@yahoo.com.br \\ Faculdade de Saúde e Ecologia Humana, Graduação em Medicina. Vespasiano, Minas Gerais, Brasil.
}

Vanderson Assis Romualdo | vandersonassis@yahoo.com.br

Fundação Hospitalar do Estado de Minas Gerais, Comitê de Ética em Pesquisa. Belo Horizonte, Minas Gerais, Brasil.

Flávio Diniz Capanema |flavio.capanema@fhemig.mg.gov.br

Fundação Hospitalar do Estado de Minas Gerais, Núcleo de Inovações Tecnológicas. Belo Horizonte, Minas Gerais, Brasil.

\section{Resumo}

O presente artigo discute aspectos éticos, científicos e jurídicos sobre o patenteamento de genes humanos, partindo de um contexto histórico sobre propriedade intelectual de seres vivos e passando pela decisão da Suprema Corte dos EUA relativa ao caso Myriad Genetics, conflito em torno da patente dos genes BRCA1 e BRCA2, relacionados ao câncer de mama e de ovário. Além disso, o artigo aborda diplomas normativos sobre o assunto, considerando tanto a legislação brasileira quanto a internacional. Por fim, contrapõe posições distintas sobre patente de genes humanos, adotando posicionamento crítico que o assunto merece.

Palavras-chaves: Patentes; Genes; Propriedade intelectual; Pesquisa em genética; Genes BRCA1; Gene BRCA2.

\begin{abstract}
This article discusses ethical, scientific and legal aspects of the patenting of human genes, starting from a historical context of intellectual property of living beings and passing through the decision of the US Supreme Court in Myriad Genetics case, conflict over patent of the genes BRCA1 and BRCA2, related to breast cancer and ovarian cancer. Moreover, the article discusses regulatory instruments on the subject, considering both the Brazilian and international legislation. Finally, it contrasts different positions on patent of human genes, adopting critical position that this matter deserves.
\end{abstract}

Keywords: Patents; Genes; Intellectual property; Genetic research; Genes BRCA1; Genes BRCA2. 


\section{Resumen}

Este artículo aborda los aspectos éticos, científicos y legales de las patentes de genes humanos, a partir de un contexto histórico dela propiedad intelectual delos seres vivosypasandoporla decisión dela CorteSuprema de Estados Unidosen elcaso MyriadGenetics, elconflictosobrepatentes delosgenes BRCA1yBRCA2 relacionados con el cáncer de mama y cáncer de ovario. Además, el artículo analiza los instrumentos normativos sobre el tema, teniendo en cuenta tanto la legislación brasileña como internacional. Por último, contrasta diferentes posiciones sobre las patentes de los genes humanos, y adopta una posición crítica que este asunto merece.

Palabras clave: Patentes; Genes; Propiedad intelectual; Investigación genética; Genes BRCA1; Genes BRCA2.

Contribuição dos autores: Os autores participaram de todas as etapas da elaboração do artigo, desde a concepção e desenho do estudo, coleta e análise das informações, redação e revisão crítica do manuscrito, sendo as duas primeiras autoras na condição de orientandas e os dois últimos autores na condição de orientadores.

Declaração de conflito de interesses: Os autores declaram não haver quaisquer conflitos de interesse.

Fontes de financiamento: A pesquisa foi realizada com financiamento da Fundação de Amparo à Pesquisa de Minas Gerais (Fapemig), através do Programa Interinstitucional de Bolsas de Iniciação Científica e Tecnológica, por um convênio entre a Fhemig e a Fapemig.

Considerações éticas: Pesquisa documental baseada em dados de domínio público de acesso irrestrito. Dessa forma, os aspectos éticos da pesquisa envolveram a honestidade na utilização das informações coletadas, respeitando-se a autoria e o conteúdo dos artigos analisados.

Histórico do artigo: Submetido: 11.set.2015 | Aceito: 02.dez.2015 | Publicado: 31.mar.2016

Licença: CC BY-NC atribuição não comercial. Com essa licença é permitido acessar, baixar (download), copiar, imprimir, compartilhar, reutilizar e distribuir os artigos, desde que para uso não comercial e com a citação da fonte, conferindo os devidos créditos de autoria e menção à Reciis. Nesses casos, nenhuma permissão é necessária por parte dos autores ou dos editores. 


\section{Introdução}

Patentes são direitos de propriedade intelectual concedidos pelo Estado que garantem aos seus titulares - pessoas físicas ou jurídicas - a exclusividade de exploração sobre suas criações, por tempo limitado. Para que o patenteamento seja viável, torna-se necessário que a matéria tenha aplicação industrial e não seja previamente conhecida. Além disso, não pode ser considerada aperfeiçoamento de uma invenção preexistente, modalidade essa definida como modelo de utilidade ${ }^{1}$.

Com o avanço da engenharia genética e da manipulação do DNA de seres vivos, o reconhecimento desses direitos tem se estendido aos recursos genéticos. Esse tipo de patenteamento cresceu tão intensamente que ultrapassou a apropriação de animais e vegetais e chegou aos genes humanos, trazendo consigo uma ampla reflexão envolvendo o meio científico e jurídico.

A discussão em torno do patenteamento de genes abrange governos, universidades, pesquisadores, empresas da área da saúde e até mesmo pacientes. Nos Estados Unidos da América (EUA) essa discussão chegou à Suprema Corte por meio do caso Myriad Genetics. Essa empresa, em um estudo conjunto com a Universidade de Utah, isolou dois genes conhecidos como BRCA1 e BRCA2, permitindo o desenvolvimento de novos testes relacionados ao câncer de mama e de ovário. Os resultados alcançados na pesquisa fizeram com que a empresa buscasse garantir os direitos de propriedade intelectual sobre o material genético isolado, gerando intenso debate no meio científico internacional a respeito desse novo paradigma ético decorrente da apropriação do patrimônio genético humano ${ }^{2}, 3$.

No âmbito jurídico internacional, verifica-se a presença de normas que permitem o patenteamento de genes em alguns países, enquanto outros consideram os recursos genéticos patrimônio coletivo. No Brasil, o registro de patente do todo ou de parte de qualquer ser vivo é proibido, por ser considerado material biológico encontrado na natureza; mesmo que isolado, só se permite o patenteamento quando se trata de material genético modificado.

Aaplicação dos direitos de propriedade intelectual sobre recursos genéticos tem como desafio a conciliação dos aspectos éticos, sociais, econômicos e científicos, que permeiam a manipulação de genes humanos. Deve-se garantir o desenvolvimento biotecnológico fundamentado, sobretudo em benefício dos pacientes. Diante disso, este artigo avalia os diversos aspectos relativos ao tema e propõe um posicionamento crítico a respeito do direito à propriedade intelectual sobre genes humanos, percorrendo diplomas normativos aplicados à matéria nos contextos mundial e nacional.

\section{Histórico}

A descoberta do DNA (Deoxyribonucleic Acid), feita em 1953 por James Watson e Francis Crick, deflagrou uma verdadeira revolução nas ciências biomédicas, a ponto de permitir o desenvolvimento do Projeto Genoma Humano com o objetivo principal de mapear todos os genes presentes no DNA humano, deflagrando um novo horizonte para a engenharia genética e trazendo consigo inovações para a área da saúde, como testes diagnósticos e novos tipos de intervenção terapêutica. Com esses novos produtos, vieram as demandas de proteção intelectual, por meio do patenteamento junto aos órgãos competentes ${ }^{4}$.

A proteção intelectual de material biológico remonta ao ano de 1873, quando foi outorgada a Louis Pasteur a patente de uma levedura utilizada no processo de fabricação da cerveja ${ }^{5}$. Um século depois, no ano de 1972, nos EUA, o pedido de patente feito por Ananda Charkrabaty sobre uma linhagem de bactérias pseudomonas modificadas geneticamente, capazes de degradar componentes de petróleo cru, deu início a um grande debate. O caso ficou conhecido como Diamond Comissioner of Patents and Trademarcks $v$. Ananda Chakrabarty, e foi decidido pela Suprema Corte em 1980, com posicionamento favorável à patente ${ }^{6}$. 
O primeiro patenteamento de plantas, o chamado caso Hibbert ${ }^{7}$, ocorreu em 1985, também após litígio judicial. Já em 1990, ainda nos EUA, foi patenteado o primeiro animal, um rato geneticamente modificado, com capacidade para desenvolver câncer de mama ${ }^{8}$. Em 1998, o isolamento de células-tronco embrionárias de humanos resultou na patente de células-tronco, pertencente à Fundação de Pesquisa Wisconsin Alumni (Warf - Wisconsin Alumni Research Foundation). A Fundação licenciou a patente a pedido da Corporação Geron para o desenvolvimento das células-tronco em seis tipos específicos de tecidos humanos. Mas o descontentamento da comunidade científica diante das limitações à pesquisa fez com que o Instituto Nacional de Saúde norte-americano interviesse, levando a Warf a assinar um termo de concordância, permitindo que cientistas de outras universidades conduzissem suas próprias pesquisas baseadas nessas patentes 9 .

Com o projeto Genoma, que totalizou um número estimado entre 30.000 a 35.000 genes sequenciados, os pedidos de patentes chegaram aos próprios genes humanos. As patentes se justificavam pelo argumento de ser o DNA uma substância química como outras que já haviam sido descobertas e patenteadas; por exemplo, a adrenalina em 1903 e a insulina em $1923^{10}$.

Entre 1980 e 2001, o United States Patent and Trademark Office (USPTO), órgão norte-americano responsável pelo registro de patentes, concedeu mais de 8.000 patentes de genes e material genético, incluindo pelo menos 1.500 sequências de material genético humano. E essa tendência mostra-se crescente, com milhares de pedidos de patente de genes humanos aguardando análise nos EUA; três das mais importantes companhias de biotecnologia norte-americanas foram responsáveis por mais de 20.000 pedidos de registro de sequências de genes humanos ${ }^{9,11}$.

Atualmente, os EUA ocupam o primeiro lugar no mundo em número de patentes de genes. Em 2005, a revista Science publicou estudo revelando que aquele país detinha a patente de 18,5\% dos 23.688 genes analisados, sendo que destes, $63 \%$ pertenciam a empresas privadas, $28 \%$ a públicas (governos, escolas, universidades, instituições de pesquisa e hospitais) e $9 \%$ não foram classificadas ${ }^{12}$.

As grandes possibilidades de lucros das indústrias de biotecnologia e demais interessados na realização de pesquisas e de testes genéticos fizeram com que surgissem novos litígios sobre infração de patentes, como se pode ver no gráfico a seguir ${ }^{13}$. 


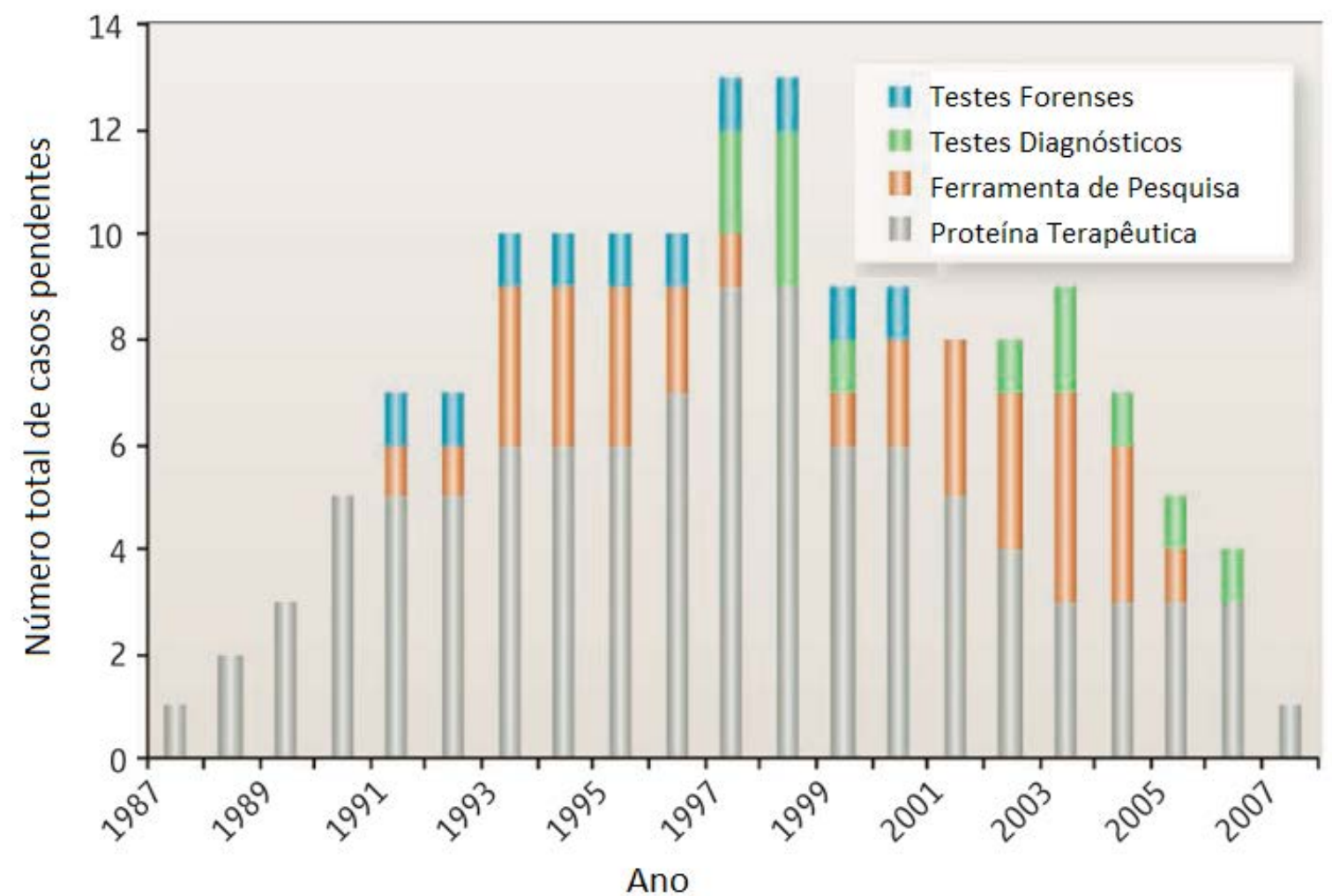

Gráfico 1. Litígios de patentes de genes humanos em pendência em cada ano a partir de 1987 até junho de 2007. Fonte: Gráfico adaptado, pelos autores, para o português. O original encontra-se disponível em http://www.patentdocs.org Obs. Dois processos resolvidos na primeira parte de 2007 não estão incluídos na contagem daquele ano.

\section{O caso Myriad}

Um dos litígios mais emblemáticos sobre o assunto ocorreu nos EUA, envolvendo a empresa Myriad Genetics, ao ser questionada sobre a patente da descrição e isolamento dos genes BRCA1 e BRCA2. A empresa obteve as patentes em 1998 após descobrir a localização e a sequência dos genes, e também as suas mutações, que aumentam drasticamente o risco de câncer de mama e ovário. Isso porque tais genes são supressores de tumor, atuando na regulação da divisão celular. A descoberta possibilitou à empresa o desenvolvimento de testes para detectar tais mutações e, consequentemente, a identificação precoce do risco do desenvolvimento de cânceres em mulheres ${ }^{14-16}$.

A Myriad Genetics detinha aproximadamente 19 patentes pelo mundo associadas aos genes BRCA1 e BRCA2, sendo oito nos EUA, quatro na Europa, quatro no Canadá, duas na Austrália e uma na Nova Zelândia. A Myriad chegou a enviar cartas para fora do país, afirmando que todos os testes genéticos para os genes deveriam ser feitos pelos laboratórios da empresa, visto que os testes genéticos disponíveis para diagnósticos de mutações nos genes BRCA1 e BRCA2 estavam cobertos pelas patentes pertencentes a ela ${ }^{11}$.

As patentes concedidas à empresa geraram pronta reação por parte de outros setores da sociedade norteamericana, que alegaram que elas estavam em desacordo com as leis do país, por serem os genes "produtos da natureza" e que prejudicavam as pesquisas médicas e os pacientes portadores dos tumores. Além disso, as patentes impunham uma restrição de ordem econômica de acesso ao teste por parte de muitas pacientes, visto que seu custo excedia ao valor de US\$ \$3.00o,oo (três mil dólares) ${ }^{2,11}$.

A nulidade das patentes foi requerida por diversas entidades, entre elas a American Civil Liberty Union que, em 2009, acionou o Tribunal Distrital de Manhattan (EUA). Em março de 2010, o juiz desse tribunal considerou as patentes como inválidas, aceitando os argumentos dos demandantes, e o Departamento de Justiça dos EUA ratificou a decisão. Em seu despacho, o magistrado argumentou que os genes são 
importantes pela informação que transmitem e que o gene isolado não é diferente do gene contido no corpo. Diante disso, muitas empresas de biotecnologia deixaram de pedir patentes de genes isolados e passaram a requerer somente patentes de genes manipulados, que o governo federal considerava patenteáveis ${ }^{2,16}$.

Já em 2011, o Tribunal Federal de Apelações, contradizendo a Corte Distrital e o governo federal americano, decidiu pela possibilidade de patentear os genes. A decisão tratou basicamente de dois temas: a patenteabilidade do DNA genômico e a patenteabilidade do DNA complementar. O primeiro tema gerou controvérsias, já que dois juízes deferiram a patente, enquanto um juiz votou pelo seu indeferimento. Nas decisões, os dois juízes favoráveis ao patenteamento afirmaram que a estrutura química do DNA isolado é diferente da presente nos cromossomos. A parte contrária, por sua vez, defendeu que os genes carregam as informações para produção de proteínas e, nesse aspecto, não há diferença entre o gene isolado e o não isolado, já que ambos contêm informações para as mesmas proteínas. Quanto ao segundo tema, todos os juízes manifestaram-se favoráveis à patente ${ }^{2,16}$.

Apesar da decisão favorável à Myriad, o Tribunal considerou não patenteável o processo de análise dos genes para verificar a existência de mutações que predispõem ao câncer. No parecer jurídico, levou-se em conta ser processo de natureza mental e abstrato e, por isso, afastado da esfera das patentes ${ }^{2}$.

A decisão suscitou grande polêmica e o caso ganhou novos capítulos. No mês de outubro de 2011, o caso chegou à Suprema Corte americana, que decidiu pelo retorno do processo ao Tribunal de Apelações, em março de 2012. Isso se deu após a Corte manifestar-se em outro caso, declarando a impossibilidade de patentear um teste sanguíneo desenvolvido pelo laboratório privado Prometheus, alegando que o teste simplesmente refletia uma lei da natureza. Em agosto de 2012, o Tribunal de Apelações reafirmou o direito da Myriad Genetics de patentear os dois genes relacionados ao câncer de mama e ovário. Porém, uma semana depois, a decisão anterior do Tribunal de Apelações foi anulada pela Suprema Corte, que determinou que o Tribunal revisasse a decisão à luz do caso Prometheus. O caso Myriad ganhou oposição de diversas entidades, entre elas a Associação Médica Americana, a March of Dimes, a American Society for Human Genetics e a Association for Molecular Pathology, suscitando nova interpelação na Suprema Corte ${ }^{17}$.

Assim, em junho de 2013, a Suprema Corte colocou fim ao longo impasse. Em sua decisão, a Corte considerou como não patenteável o DNA genômico e indeferiu o pedido dos autores, considerando patenteável somente o DNA complementar. Segundo a Corte, evidenciou-se que a Myriad não criou nem modificou a informação contida nos genes BRCA 1 e BRCA 2, nem tampouco criou ou alterou a estrutura genética dos genes. O que a empresa promoveu foi descobrir a localização e sequência dos genes dentro dos cromossomos 17 e 13 e isolar os genes do material genético, mas isso não converteu os genes em composição de matéria com direito à patente ${ }^{14,16}$.

Já com relação ao DNA complementar, que é uma molécula de DNA recomposta a partir de uma de RNA produzida pelo gene, a Corte argumentou que se trata de uma molécula que contém apenas éxons e por isso difere da molécula natural. Nesse caso, apesar da sequência de nucleotídeos ser a mesma do gene encontrado na natureza, segundo entendimento da Corte o cientista criou algo novo, sendo, portanto, patenteável nos termos da legislação norte-americana ${ }^{14,16}$.

Este posicionamento da Suprema Corte mereceu outros questionamentos. Segundo Bergel ${ }^{16}$, a informação genética do DNA complementar é a mesma do DNA genômico e, por isso, não se trata de um trabalho criativo. Já como afirma Jeff $\mathrm{Guo}^{19}$, os genes são basicamente informação e esta não pode ser patenteada. Soma-se a isso o fato de a Corte não ter se manifestado se o DNA complementar atende aos demais requisitos de patenteabilidade além de ser uma novidade, que são a presença de atividade inventiva e utilidade industrial. Por isso, a decisão da Suprema Corte trata de forma superficial um tema de grande importância ${ }^{14,16,18}$. 


\section{Marco regulatório}

Os direitos de propriedade intelectual são os direitos correspondentes às criações humanas e tem como um de seus instrumentos jurídicos, as patentes, destinadas às criações que têm aplicação industrial. No Brasil, elas são concedidas por um escritório nacional - o Instituto Nacional de Propriedade Industrial (INPI) - com validade em todo o território nacional ${ }^{19}$.

O ordenamento jurídico brasileiro aplicado à proteção intelectual de matéria viva só permite patentes para microorganismos geneticamente modificados, assim como o direito de proteção de cultivares de plantas, mesmo sem modificações genéticas. No caso das plantas e dos animais (o todo ou partes dele), assim como das sequências de DNA de qualquer espécie de ser vivo, a legislação brasileira os define como não patenteáveis ${ }^{8}$.

Nos termos do art. 10, inciso IX, da Lei 9.279/96 - que regula direitos e obrigações relativos à propriedade industrial - não são consideradas invenções "o todo ou parte de seres vivos naturais e materiais biológicos encontrados na natureza, ou ainda que dela isolados, inclusive o genoma ou germoplasma de qualquer ser vivo natural e os processos biológicos naturais" ${ }^{20}$.

Completando o artigo anterior, o art. 18, inciso III, afirma que "o todo ou parte dos seres vivos não são patenteáveis, exceto os microorganismos transgênicos que atendam aos três requisitos de patenteabilidade - novidade, atividade inventiva e aplicação industrial - e que não sejam mera descoberta”.

Vale ressaltar que já está tramitando no Congresso Nacional, o Projeto de Lei do Código Nacional de Ciência, Tecnologia e Inovação 2177/201, apresentado em 31 de agosto de 2011, que resulta de sugestão apresentada pela Sociedade Brasileira para o Progresso da Ciência juntamente com a Academia Brasileira de Ciências, o Conselho Nacional de Secretários Estaduais para Assuntos de CT\&I e o Conselho Nacional das Fundações Estaduais de Amparo à Pesquisa ${ }^{21}$. Segundo o art. 32, de tal projeto: $O$ acesso à amostra de componente do patrimônio genético e de conhecimento tradicional associado para fins exclusivos de pesquisa e desenvolvimento nas áreas biológicas e afins, em quantidades razoáveis, nos termos de regulamentação, independerá de autorização prévia. Parágrafo único. A extração de componente do patrimônio genético para fins de produção e comercialização depende de autorização do Conselho de Gestão do Patrimônio Genético, vinculado ao Ministério do Meio Ambiente.

As diretrizes para análise ética e tramitação dos projetos de pesquisa no Brasil são regidas pela Resolução 466/2012 do Conselho Nacional de Saúde - Ministério da Saúde (CNS-MS). Porém, existe uma resolução complementar específica para da área de genética humana, que é a $\mathrm{N}^{\circ} 340$ do CNS-MS. A resolução prioriza a proteção do indivíduo e a obrigatoriedade desse tipo de estudo ter de ser aprovado no Comitê de Ética em Pesquisa (CEP) da instituição de origem; em seguida, o projeto deve ser enviado e aprovado pela Comissão Nacional de Ética em Pesquisa (Conep) que é a instância magna de discussão no país, situada em Brasília dentro do próprio MS. O sistema CEP-Conep não tem nenhuma legislação ou ação preestabelecida com relação ao direito de patente e propriedade intelectual de genes humanos ${ }^{22}$.

No âmbito internacional, alguns países também aceitam a concessão de direitos de propriedade intelectual por meio de patentes para plantas, animais e microorganismos transgênicos. No entanto, extrapolam o entendimento do legislador brasileiro, ampliando a possibilidade para sequências específicas de DNA - em destaque os Estados Unidos, Japão e México - além dos direitos de proteção de cultivares²3.

Com entendimento diverso, outros países criticam veementemente a apropriação do patrimônio genético de seres vivos. Não há convergência de entendimento nem mesmo entre os países integrantes do projeto Genoma Humano ${ }^{24}$.

Muitas entidades e especialistas consideram que o código genético, sobretudo o do ser humano, é patrimônio inalienável de toda a humanidade. Nesse sentido, destacam-se as diretrizes da Declaração Universal sobre o Genoma Humano e os Direitos Humanos, adotada pela Unesco em $1997^{25}$. No art. 4, 
a Declaração orienta que "o genoma humano em seu estado natural não deve ser objeto de transações financeiras”. Já no art. 12 afirma que os benefícios das pesquisas e suas aplicações devem se estender a toda humanidade:

a) benefícios dos avanços na biologia, na genética e na medicina, relacionados ao genoma humano, devem ser disponibilizados a todos, com a devida consideração pela dignidade e pelos direitos humanos de cada indivíduo.

b) A liberdade da pesquisa, necessária ao avanço do conhecimento, é parte da liberdade de pensamento. As aplicações da pesquisa, incluindo aquelas realizadas nos campos da biologia, da genética e da medicina, envolvendo o genoma humano, devem buscar o alívio do sofrimento e a melhoria da saúde de indivíduos e da humanidade como um todo.

Nessa mesma declaração, no art. 15, evidencia-se o papel desempenhado pelo Estado de garantir as pesquisas com genes: Os Estados devem tomar as providências necessárias para constituir uma base para o livre exercício da pesquisa sobre o genoma humano, respeitando os princípios estabelecidos na presente Declaração, de modo a salvaguardar o respeito aos direitos humanos, às liberdades fundamentais e à dignidade humana e a proteção da saúde pública [...]

Sobre a Cooperação entre Estados, a Declaração afirma nos artigos 17 e 18:

Art. 17. Os Estados devem respeitar e promover a prática da solidariedade com os indivíduos, as famílias e os grupos populacionais que são particularmente vulneráveis a, ou afetados por, doenças ou deficiências de caráter genético. Eles devem fomentar pesquisas "inter alia" sobre a identificação, prevenção e tratamento de doenças de fundo genético e de influência genética, em particular as doenças raras e as endêmicas, que afetam grande parte da população mundial.

Art. 18. Os Estados devem envidar todos os esforços, levando devidamente em conta os princípios expostos nesta Declaração, para continuar fomentando a disseminação internacional do conhecimento científico relativo ao genoma humano, a diversidade humana e as pesquisas genéticas e, a esse respeito, para fomentar a cooperação científica e cultural, especialmente entre os países industrializados e os países em desenvolvimento.

\section{Discussão}

As ciências biológicas sofreram importante transformação após a descoberta da estrutura do DNA em 1953. Em 1990, foi estabelecido o projeto Genoma Humano para coordenar a pesquisa com o objetivo de identificar todos os genes no DNA humano. Quando o projeto concluiu o sequenciamento do genoma humano, logo ficou evidente que toda aquela informação teria um valor significativo, e torná-la disponível gratuitamente a todos seria abrir mão de uma importante oportunidade de negócio. Diante disso, desde então, observou-se um grande número de pedidos de patentes a serem concedidas sobre sequências de DNA, o que suscitou a discussão sobre a legitimidade dessa prática.

Sabe-se que as patentes estimulam o desenvolvimento de pesquisas, uma vez que oferecem ao criador a proteção que impede a cópia, produção ou comercialização do produto por terceiros, durante a sua vigência, concedendo ao inventor retorno financeiro e reconhecimento. Outra contribuição das patentes é a de atrair investimentos elevados para pesquisas, ao oferecer maior segurança ao investidor. Além disso, são capazes de promover o progresso científico por meio da divulgação das novas criações. O pesquisador torna pública a sua invenção, ampliando o conhecimento da comunidade científica e estimulando ideias para o desenvolvimento de novas criações ${ }^{26}$. 
Apesar de todos os benefícios provenientes dos direitos de propriedade intelectual, questiona-se se a extensão desses direitos ao material genético humano está atingindo seus objetivos, principalmente o de estimular a inovação, promovendo o interesse público. Além disso, considerando as questões ético-jurídicas em torno do patenteamento, argumenta-se que o DNA humano possui uma natureza peculiar e que a patente de DNA não atende aos critérios legais para o patenteamento, por isso não deve ser permitida ${ }^{27}$.

No que se refere à inovação, se considerarmos que a patente sobre um novo produto químico, no caso o gene, cobre todos os usos sobre o produto, mesmo se não forem descritos pelo titular, fica evidente que a patente de gene pode se tornar um entrave ao desenvolvimento de novas pesquisas ${ }^{16}$.

Nesse sentido, numa pesquisa divulgada nos EUA envolvendo 211 laboratórios que desenvolviam testes genéticos, $53 \%$ afirmaram não ter desenvolvido uma pesquisa de teste ou serviço, desencorajados pela política de patentes, e 25\% afirmaram que foram impedidos de realizar serviços que haviam desenvolvido e estavam oferecendo devido a patentes prévias. Dessa forma, o avanço científico mostra-se dependente da aquisição do direito de múltiplas patentes, sendo que, atualmente, não há regras para evitar a cobrança de taxas abusivas, e o custo cumulativo dessas licenças seria muito alto, tornando muitas dessas pesquisas inviáveis ${ }^{28}$.

Além de limitar novas pesquisas, as patentes de genes afetam seus resultados práticos, que são cada vez mais demorados como, por exemplo, no desenvolvimento de testes diagnósticos. Dos casos estudados pela Secretary's Advisory Committeeon Genetics, Health and Society (SACGHS), os testes mais rapidamente criados foram aqueles que não possuíam patentes envolvidas ${ }^{26}$.

Sobre as questões ético-jurídicas, muitos consideram que o DNA isolado tem natureza diversa do DNA encontrado no corpo humano. Assim, a simples tarefa de se isolar o DNA o torna apropriável pelos direitos de propriedade intelectual. Nesse sentido, agências responsáveis pelo registro e concessão de patentes, como a USTPO nos EUA, a European Patent Office (EPO) e a Japan Patent Office (JPO) emitiram um comunicado em 1988 afirmando que "os produtos naturais purificados não são considerados produtos naturais ou simplesmente descobrimentos, já que não existem na natureza de forma isolada"16.

Por outro lado, diz-se que o caráter informativo dos genes, que são portadores de informação genética, os torna afastados da esfera das patentes, uma vez que não é razoável submeter uma informação que pertence ao mundo natural ao domínio de alguém que simplesmente revelou tal informação pelo isolamento do gene ${ }^{16}$.

O genoma, conforme declaração da Unesco, é "a base da unidade fundamental do todos os membros da família humana, bem como de sua inerente dignidade e diversidade”. Não é simplesmente uma substância química que pode ser apropriada pelo homem. O genoma caracteriza a espécie e difere a espécie humana das demais. Submeter tal informação ao direito de propriedade intelectual é absurdo se considerarmos que isso seria nomear alguém como titular da informação genética da espécie humana ${ }^{16}$.

\section{Conclusão}

A introdução da manipulação genética nas pesquisas biomédicas trouxe consigo inúmeros benefícios, como o desenvolvimento de testes diagnósticos, novos produtos imunobiológicos e aplicações terapêuticas diversas. Com os benefícios à saúde vieram também as possibilidades de retornos financeiros expressivos para os pesquisadores e indústrias, que buscaram se resguardar por meio do registro de patentes. Porém, apesar dos benefícios que as patentes oferecem, o processo de patenteamento de genes humanos tem se tornado uma barreira ao desenvolvimento de novas pesquisas, resultando em severa restrição à produção de novos insumos e ao acesso de muitos pacientes a esses produtos.

Se considerarmos a natureza do DNA, sua descrição ou composição pelo pesquisador não transformam uma mera descoberta em uma invenção humana. Além disso, tratar os genes como invenções patenteáveis baseando-se apenas em uma de suas funções, como codificar uma proteína ou associar-se a uma doença, é limitar uma estrutura que atualmente tem se mostrado multifuncional. 
A Suprema Corte dos Estados Unidos, que teve a oportunidade de se posicionar criticamente diante do tema, optou por posicionar-se favoravelmente à patente do DNA complementar. Esperava-se um parecer diferente, porém mais uma vez os interesses econômicos prevaleceram diante dos princípios jurídicos e éticos.

\section{Referências}

1. Instituto Nacional da Propriedade Industrial [Internet]. Guia Básico de Patente. [citado 5 jun 2015]. Disponível em: http://www.inpi.gov.br/menu-servicos/patente/guia-basico-de-patente

2. Pollack A. Ruling Upholds Gene Patent in Cancer Test [Internet]. New York Times. 2011 jul. [cited 2015 jun5]. Available from: http://www.nytimes.com/2011/07/30/business/gene-patent-in-cancer-test-upheldby-appeals-panel.html? $\quad r=2$

3. Pollack A. Justices Send Back Gene Case [Internet]. New York Times. 2012 mar [cited 2015 jun 5]. Available from: http://www.nytimes.com/2012/03/27/business/high-court-orders-new-look-at-genepatents.html? $r=0$

4. National Human Genome Research Institute. [Internet]. An Interactive Timeline of the Human Genome [cited 2015jun7]. Available from: http://www.genome.gov/10001772

5. World Intellectual Property Organization [Internet]. Wipo Magazine. Bioethics and Patent Law: The Relaxin Case. 2006. [cited 2015 jun7]. Available from: http://www.wipo.int/wipo magazine/en/2006/02/ article 0009.html

6. Robinson D, Medlock N, Diamond V.Chakrabarty: A Retrospective on 25 Years of Biotech Patents. IntellectualProperty\& Technology Law Journal. 17 (10): 12-15.

7. DronamrajuK. Emerging Consequences of Biotechnology: biodiversity loss and IPR issues. Singapore: Word Scientific; 2008.

8. Faria CRSM. Patentes biológicas. Brasília: Senado Federal; 2001 [citado 8 jun 2015]. Disponível em: http://www2.senado.leg.br/bdsf/handle/id/144

9. Drutman L. Está nos genes: barreiras de patentes na pesquisa genética. ComCiência. Sociedade Brasileira para o Progresso da Ciência. 2006 [citado 10 jun 2015]. Disponível em: http://www. comciencia. br/comciencia/?section $=8 \&$ edicao $=8 \& \mathrm{id}=47$

10. DutfieldG. DNA patenting: implications for public health research. Bulletin of the World Health Organization. 2006 may; 84 (5). 388-392.

11. Paradise J. European Opposition to Exclusive Control Over Predictive Breast Cancer Testing and the Inherent Implications for U.S. Patent Law and Public Policy: A Case Study of the Myriad Genetics BRCA Patent Controversy. FoodandDrug Law Journal. 2004; 59 (1). 133-154.

12. Jensen K, Murray F. Intellectual property landscape of the human genome. Science, 2005; 310, p. 239240.

13. ZuhnD. Science Article Should Help Allay Gene Patenting Fears. Patent Docs. 2008 dez 17. [cited 2015 jun17]. Available from: http://www.patentdocs.org/2008/12/science-article-should-help-allay-fearsconcerning-gene-patents.html

14. Supreme Court of the United States. Association for Molecular Pathology, et al. versus Myriad Genetics, inc., et al. On Writ of Certiorari to the United States Court of Appeals for the Federal Circuit. Argued April 15, 2013, Decided June 13, 2013. [cited 2015 jun17]. Available from: http://www.supremecourt.gov/ opinions/12pdf/12-398 1b7d.pdf

15. Franceschi M. Droit etmarchandisation de la connaissance sur les gens humains. Paris: Edit. CNRS; 2004. p. 186. Apud Bergel, SD. Enfoque ético-jurídico de la sentencia de la Corte Suprema de los Estados Unidos sobre patentabilidad de genes humanos. RevBioét. 2014, 22 (1): 18-27.

16. Bergel SD. Enfoque ético-jurídico de la sentencia de la Corte Suprema de los Estados Unidos sobre patentabilidad de genes humanos. RevBioét. 2014, 22 (1): 18-27.

17. Reuters. Court Reaffirms Right of Myriad Genetics to Patent Genes [Internet]. New York Times. 2012 ago. [cited 2015 jun7]. Available from: http://www.nytimes.com/2012/08/17/business/court-reaffirmsright-of-myriad-genetics-to-patent-genes.html? $r=0$ 
18. Jeff-Guo. The Supreme Court reveals its ignorance of genetics. New Republic 13 June 2013. [cited2014 jan15].Available from: http://www.newrepublic.com/article/113476/supreme-courtgenetics-rulingreveals-judges-ignorance\#

19. Jungmann DM. Inovação e Propriedade Intelectual: guia para o Docente. Brasília: Senai; 2010. [citado 8 jun 2015]. Disponível em: http://www.inpi.gov.br/sobre/arquivos/guia docente iel-senai-e-inpi.pdf

20. Brasil. Lei no 9.279, de 14 de maio de 1996. [citado 16 jun 2015]. Disponível em: http://www.planalto. gov.br/ccivil 03/Leis/L9279.html

21. Universidade Federal de Minas Gerais. Projeto de Lei apresentado ao Congresso propõe novo marco legal para C\&T no país. 2011 set. [citado 20 jun 2015]. Disponível em: https://www.ufmg.br/online/ arquivos/020757.shtml

22. Brasil. Ministério da Saúde. Conselho Nacional de Saúde. Comissão Nacional de Ética em Pesquisa (CONEP). Resolução No 340, de 8 de julho de 2004. [citado 18 jun 2015]. Disponível em: http:// conselho.saude.gov.br/resolucoes/2004/Reso340.doc

23. VarellaMD, BorgesR C B (Orgs.). O novo direito da biogenética. O novo em direito ambiental. Belo Horizonte: Del Rey, 1998

24. Brice P. Gene patent upheld by British Supreme Court [Internet]. Phgfoundation. 2011 nov. [cited2015jun10]. Available from: http://www.phgfoundation.org/news/10461/

25. Organização das Nações Unidas para a Educação, a Ciência e a Cultura. Declaração Universal sobre o Genoma Humano e os Direitos Humanos. Unesco; 1997.[citado 24 jun 2015]. Disponível em: http:// unesdoc.unesco.org/images/0012/001229/122990por.pdf

26. Gene Patents and Licensing Practices and Their Impact on Patient Access ot Genetic Tests. Report of the Secretary's Advisory Committee on Genetics, Health and Society. 2010apr.[cited 2015 jun 10]. Available from: http://osp.od.nih.gov/sites/default/files/SACGHS patents report 2010.pdf

27. The ethics of patenting DNA: a discussion paper. Report of Nuffield Council on Bioethics. London, 2002. [cited2015jul1]. Available from: http://nuffieldbioethics.org/wp-content/uploads/2014/07/The-ethics-ofpatenting-DNA-a-discussion-paper.pdf

28. Cho MK et al. Effects of Patents and Licenses on the Provision of Clinical Genetic Testing Services. J Mol Diagn. 2003 Feb; 5(1): 3-8. 